The authors of this work are geographically close to each other, and the preface mentions a series of in-person meetings. Could collaborative authorship, in which experts think and write together, produce chapters that maintain the current volume's high scholarly quality, but while achieving a truly global reach? Could the wide-geography analysis of big data or of religious networks reveal trends invisible at the regional level?

Nevertheless, to raise these questions in no way detracts from the value of this volume as a compendium of dependable and up-to-date histories of early modern Christianities. Jesuits make at least a brief appearance in every chapter, and receive more sustained attention in the chapters on seventeenthcentury Europe, Asia, and the Iberian empires. The scholar of Jesuit Studies will find the volume useful primarily as a convenient collection of background information.

\author{
Luke Clossey \\ Simon Fraser University \\ lclossey@sfu.ca \\ DOI:10.1163/22141332-00603006-01
}

William A. Pettigrew \& David Veevers, eds.

The Corporation as a Protagonist in Global History, c.1550-1750. Global Economic

History Series 16. Leiden: Brill, 2019. Pp. 344. Hb, \$157.00.

This collection of fourteen essays is divided in two parts: ten essays analyzing different English corporations and four papers evaluating European counterparts such as the Scandinavian, French, Iberian, and Dutch merchant companies. Part one is organized thematically: in $23^{2}$ pages, the global English corporations are examined in terms of political economy, migration, networks, literature, religion, governance, gender, architecture, science, and scholarship, whereas part two (much more succinct at a mere forty-six pages) compares and contrasts continental European companies to the English case studies from part one.

Pettigrew and Veevers aim to engage historians of empire, business, trade, and law. First and foremost, the authors seek to contribute to the field of global history; they propose several methodological approaches in their introduction, arguing that their essays on corporations are not simply comparative or connective global history, but instead an integrative history. To do this they combine comparative and connective approaches with a study of globalization (10), in order to demonstrate that companies were protagonists in 
building a network and institution that "integrated the local, the national, and the global" (13). Pettigrew and Veevers emphasize two important perspectives to make this approach more concrete: unlike earlier scholarship on European corporations, all contributions in this volume include non-Europeans as "key stakeholders" in their narrative, with a critical role in forcing the European corporation to become "truly global" (15). However culturally, economically, and institutionally homogenous the corporation aimed and claimed to be at home, it was precisely their intensifying interactions with non-Europeans that changed their essence and ensured their development into protagonists in global history. This viewpoint is a much-needed historiographic evolution in the history of corporations.

A second approach is Pettigrew and Veevers's emphasis that corporations should no longer be studied within a national context, still less in the narrower focus of one particular corporation based in one nation (11-12). This is also a welcome attitude, and it mirrors a historiographic development in the field of Jesuit studies as well, where scholars are encouraged to study Jesuits together with other missionary orders, for example, or to study Jesuit missionaries of multiple nationalities in more than one region. Part one of The Corporation studies a wide variety of English corporations and avoids narrowingly analyzing just one English corporation in one part of the globe. However, three of the four chapters on non-English corporations clock in at fewer than ten pages (excluding footnotes and bibliography). The brevity of the contributions in part two means that there is less room to investigate the themes from part one in depth, let alone for examining thoroughly the connections and comparisons between English and non-English corporations. This unbalanced structure reinforces the predominant focus on the corporations of one nation, Britain.

Finally, Pettigrew and Veevers introduce a distinctive global sociology of the corporation, as outlined in five qualities that reflect the extent to which corporate networks were built on a global scale and with critical input from non-European agents. Corporations thrived thanks to their ability to develop durable, intercultural relationships based on negotiation. Furthermore, they were not monopolies in their global operations, but organizations with a rather porous membership, able to structure international relationships in an integrative manner, while deploying a jurisdictional evasiveness (19). Overall, the authors thus advance Maxine Berg's approach in using the corporation as it "recast Europe from the 'knowing' subject to the 'object' of Global History" (28, 188). This too is a wonderful goal.

Part one starts with Pettigrew's analysis of the changing attitudes of corporations with respect to British political economy. In line with the volume's historiographic approach, Pettigrew argues that the unenforceability of chartered 
monopolies, the interloping of merchants, and the development of inclusive business relationships with non-European peoples were critical to how corporations evolved ideas and practices about political economy. Later chapters in part one, such as Aske Laursen Brock's essay on networks, make other qualities of the global sociology of corporations more concrete, by drawing attention to the flexibility of English corporations. This allowed them to thrive in the "messiness" of the early modern world precisely because corporations incorporated existing family, personal, and non-European networks while providing a durable structure (97). In line with several other chapters, Brock zooms in on the ties between English and non-European partners, without solely focusing on success stories. Madras merchants, for example, were ruined by their joint stock arrangements with the English. More established networks such as those of Armenian traders did not have such a dependent and one-sided relationship with the English.

The network of the Society of Jesus is mentioned throughout the volume. Haig Smith's chapter on religion in part one focuses on how English corporations organized and policed "the religious lives of their members" (137). Smith counterposits "the aggressive evangelism of Jesuits and Portuguese Catholics" to the more passive and negotiated approach of the English East India Company in Bombay and Madras (151). Smith uses this contrast to further illustrate the compromising character of the global sociology of corporations. Anna Winterbottom, in her analysis of the intersections of science and global trading companies, also touches upon the Jesuits. Winterbottom emphasizes the Jesuit contributions to the fields of astronomy and mathematics and their role in connecting European and Chinese science before the eighteenth century. She claims that since no EIC servants or British scholars studied astronomy in-depth before the mid-eighteenth century, there were similarly no direct contacts between Protestant Britain and the Catholic missionary order (249). This is somewhat surprising since these two groups did collaborate on occasion, especially when it came to the safe transport of people, letters, books, and money. EIC servants in India were responsible for transporting the profits from Jesuit investments from India to China from the early eighteenth century onwards, while Jesuit and other Catholic missionaries did on occasion mention how valuable the English network was for intra-Asian travel and the transport of goods, or how crucial it was to have connections in London to ensure reliable transport of letters and material goods between Asia and Europe.

Some of the harder questions for the proposed approaches and methodologies of this volume are asked in part two. Lisa Hellman, for example, wrote the chapter on Scandinavian networks and wonders, "[i]f there was a global community $[. .$.$] and its networks were global and non-national, can their existence$ 
support a distinct British corporate sociology and governance?" (284). Leonard Hodges, who wrote the chapter on French corporations, similarly questions the "Goldilocks zone" between state and private control of the British companies (290). These critical questions will keep pushing future scholarship on the global nature of early modern European corporations, in an effort to write integrative global history.

\author{
Frederik Vermote \\ California State University Monterey Bay \\ fvermote@csumb.edu \\ DOI:10.1163/22141332-00603006-02
}

\title{
Dominic Sachsenmeier
}

The Global Entanglements of a Man Who Never Traveled. New York: Columbia University Press, 2018. Pp. $\mathrm{x}+270$. Hb, \$6o.oo.

The Global Entanglements of a Man Who Never Traveled by Dominic Sachsenmeier is a fascinating book and an important contribution to the study of global Christianity and the Jesuit presence in China in the early modern period. The man who never traveled in the book's title is Zhu Zongyuan (Ch: 朱宗元), a Chinese convert from Ningbo, a port city located across the Hangzhou Bay from present-day Shanghai, in China's Zhejiang province. Zhu, who received the name Cosmas after baptism, was probably born around 1616 in a family of provincial officials. This enabled him to earn a solid education and passed the first levels of provincial examinations achieving the ranks of degree candidate (Ch: shengyuan 生員 in 1646) and provincial graduate (Ch: juren 舉人 in 1648). In terms of social hierarchy, Zhu Zongyuan decidedly did not reach the level of the three pillars of Chinese Catholicism, Xu Guangqi 徐光啓, Li Zhizao 李之 藻, and Yang Tingyun 楊廷䄏 who were literati of the highest level with posts at the imperial court in Beijing. But Zhu was still part of the elite at the local level and an active scholar, who wrote two remarkable books in support of Christianity from his vantage point: Summary of World Salvation (Ch: Zhengshi lüeshuo 拯世略說) and Responses to a Guest's Questions (Ch:Dakewen 答客聞).

Dominic Sachsenmeier breaks new ground by tackling the figure of Zhu Zongyuan. First, in the historiographical sense, by working on a set of materials, which have not been previously elucidated. To be sure, the historian Fang Hao had known about Zhu, and included him in his reference works about the history of Christianity in China. Sachsenmeier is however the first to properly interpret Zhu's work and role in the China mission and in the context of the end 